\title{
Recombinant pharmaceuticals from microbial cells: a 2015 update
}

\section{Open Acces:}

\author{
Laura Sanchez-Garcia 1,2,3, Lucas Martín ${ }^{4}$, Ramon Mangues ${ }^{5}$, Neus Ferrer-Miralles ${ }^{1,2,3}$, Esther Vázquez 1,2,3 \\ and Antonio Villaverde ${ }^{1,2,3^{*}}$ (I)
}

\begin{abstract}
Diabetes, growth or clotting disorders are among the spectrum of human diseases related to protein absence or malfunction. Since these pathologies cannot be yet regularly treated by gene therapy, the administration of functional proteins produced ex vivo is required. As both protein extraction from natural producers and chemical synthesis undergo inherent constraints that limit regular large-scale production, recombinant DNA technologies have rapidly become a choice for therapeutic protein production. The spectrum of organisms exploited as recombinant cell factories has expanded from the early predominating Escherichia coli to alternative bacteria, yeasts, insect cells and especially mammalian cells, which benefit from metabolic and protein processing pathways similar to those in human cells. Up to date, around 650 protein drugs have been worldwide approved, among which about 400 are obtained by recombinant technologies. Other 1300 recombinant pharmaceuticals are under development, with a clear tendency towards engineered versions with improved performance and new functionalities regarding the conventional, plain protein species. This trend is exemplified by the examination of the contemporary protein-based drugs developed for cancer treatment.
\end{abstract}

Keywords: Recombinant proteins, Protein drugs, Recombinant DNA, Fusion proteins, Biopharmaceuticals

\section{Background}

Human cells produce thousands of proteins that integrated into an extremely complex physiologic network perform precise actions as catalysers, signalling agents or structural components. Then, dysfunction of proteins with abnormal amino acid sequences or the absence of a given protein often results in the development of severe pathologies such as diabetes [1], dwarfism [2], cystic fibrosis [3], thalassaemia [4] or impaired blood clotting [5], among many others [6,7]. In the absence of standardized gene therapy treatments that would genetically reconstitute functional protein production within the patient, protein deficiencies must be treated by the punctual or repeated clinical administration of the missing protein, so as to reach ordinary functional concentrations. These therapeutic proteins are produced ex vivo

\footnotetext{
*Correspondence: Antoni.Villaverde@uab.cat

${ }^{1}$ Institut de Biotecnologia i de Biomedicina, Universitat Autònoma de

Barcelona, 08193 Bellaterra, Cerdanyola del Vallès, Spain

Full list of author information is available at the end of the article
}

mostly in biological systems [8], which must guarantee not only full protein functionalities but also a cost-effective industrial fabrication and the absence of hazardous contaminants. Protein drugs have to necessarily conform to quality constrains stricter than those expected in the production of enzymes for chemical industries, which consequently defines the choice of recombinant hosts, protocols and production strategies. Nowadays, there are over 400 marketed recombinant products (peptides and proteins) and other 1300 are undergoing clinical trials (figures updated on May 2015 [9]).

In this context of expanding protein drug markets, there is a generic consensus about the need to enable drugs for cell- or tissue-targeted delivery to reduce doses, production costs and side effects. While increasing protein stability in vivo can be reached by discrete modifications in the amino acid sequence, generating fusions between therapeutic proteins and specific peptide ligands or antibodies that interact with particular cell receptors might allow acquiring specificity in the delivery process. 
In this regard and also pushed by the convenience to combine diagnosis and therapy in theranostic agents [10, 11], contemporary research on protein pharmaceuticals tends towards engineered versions functionally more sophisticated than plain natural polypeptides.

\section{Review \\ Cell factories}

Since early recombinant DNA times, ever-increasing understanding of cell physiology and stress, and of factors involved in heterologous gene expression and protein production empowered the use of different living factories, namely prokaryotic and eukaryotic cells, plants or animals $[12,13]$. By using these systems, recombinant production solves source availability problems, is considered a bio-safe and green process and confers the ability to modify amino acid sequences and therefore protein function, to better adjust the product to a desired function [14]. There is a wide and growing spectrum of expression systems that are becoming available for the production of recombinant proteins $[15,16]$. Escherichia coli was the prevalent platform when the biopharmaceutical sector emerged in the 1980s, and it was followed by the implementation of the yeast Saccharomyces cerevisiae. Both systems and the associated genetic methodologies exhibit an unusually high versatility, making them adaptable to different production demands [17]. Despite the exploration of insect cells as initially successful system especially for vaccine-oriented proteins, mammalian cell lines (most notably CHO cells) are nowadays the prevailing animal-derived cell system due to their suitability to produce conveniently glycosylated proteins $[18,19]$ (Fig. 1). The ability to carry out post translational modifications contrasts with complex nutritional requirements, slow growth and fragility, and relatively high production timing and costs. Thus, among many conventional and emerging cell-based systems for protein production, bacteria, yeast and mammalian cell lines are the most common in biopharma, and both prokaryotic and

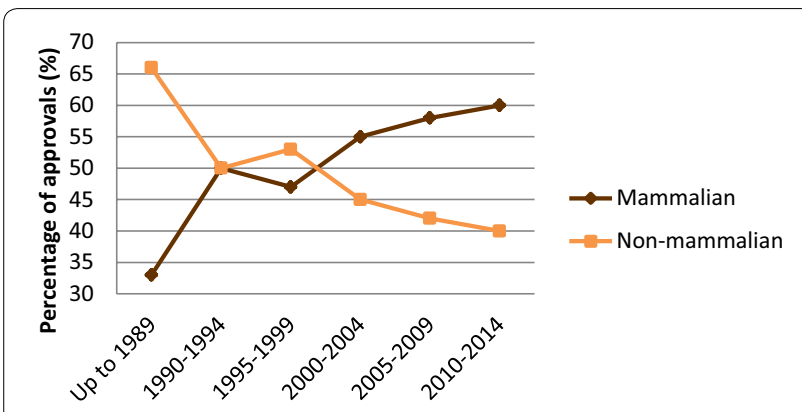

Fig. 1 Number of recombinant protein products approved for use as drugs in humans, depending on the type of production platform eukaryotic systems are constantly evolving and competing to improve their properties and intensify as platforms of choice for protein drug production [14]. While bacteria has lost its early leading role in the field [19], about $30 \%$ of marketed biopharmaceuticals are still produced in this system [20], as supported by the unusual physiological and genetic manipulability of prokaryotic cells [21].

In fact, the main purpose in the development of new protein production platforms is to enhance drug functionality through reaching successful protein folding and post-translational modifications, while keeping the low complexity and high flexibility associated to prokaryotic cell culture. In this context, Gram-positive bacteria such as Bacillus megaterium [22] and Lactococcus lactis [23] allow efficient protein secretion in absence of endotoxic cell wall components, while filamentous fungi (such as Trichoderma reesei, [24]), moss (Physcomitrella patens, $[25,26])$ and protozoa (Leishmania tarentolae, [27-29]) promote glycosylation patterns similar to those in mammalian proteins but being still cultured through methods simpler than those required by mammalian cells. Extensive descriptions of emerging (bacterial and non-bacterial) platforms specifically addressed to the production of high quality protein drugs can be found elsewhere [15, 16, 21]. The recent development of an endotoxin-free strain of E. coli [30] and its application to the fabrication of proteins and protein materials [30-32] paves the road for a cost-efficient and versatile production of proteins intended for biomedical uses by skipping endotoxin removal steps, thus gaining in biosafety and reducing production costs [33]. Hopefully, all these new systems would soon offer improved products in still simple and fully controlled biofabrication approaches.

\section{Trends in protein biopharmaceuticals}

Nearly 400 recombinant protein-based products have been successfully produced and are approved as biopharmaceuticals [9], a term that refers to therapeutic products generated by technologies that involve living organisms [34]. Other 1300 protein candidates are under development, of which around $50 \%$ are in pre-clinical studies and other $33 \%$ in clinical trials [9] (Fig. 2). In this context, an increase in the number of approvals in next years is predictable. Developed by Eli Lilly \& Co in the 70's, Humulin, a recombinant human insulin fabricated in the bacterium E. coli [35], was the first approved biopharmaceutical (by the FDA) in 1982 [36, 37]. Other natural proteins such as hormones, cytokines and antibodies (Orthoclone OKT3) were among the single nine products approved in 1980s (Table 1). Nowadays, the therapeutic areas that have benefited more from recombinant biopharmaceuticals are metabolic disorders (e.g. diabetes 


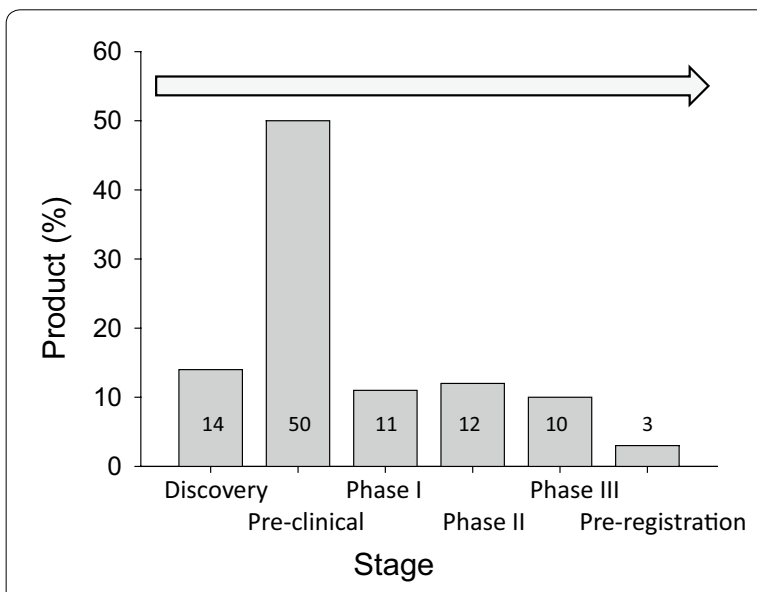

Fig. 2 Workflow involved in the development of a new drugs and approximate percentage (bars and numbers) of recombinant proteins currently in each step [9]

type 1 , type 2 , obesity or hypoglycaemia), haematological disorders (e.g. renal anaemia, haemophilia A, bleeding or clotting disorders) and oncology (e.g. melanoma, breast or colorectal cancer), with 24,18 and $15 \%$ of the approvals respectively (Fig. 3). In this regard, oncology is a clearly expanding market. In the period 2010-2014, 9 out of 54 approved biopharmaceuticals were antitumoral drugs, cancer representing the most common indication within this period. Digging into the molecular bases of biopharmaceuticals, there is a clear trend towards antibody-based products. Over the same period (20102014), 17 of the 54 protein drugs approved were monoclonal antibodies (31.5\%), compared with $11 \%$ over 1980-1989 [22]. Furthermore, among the top ten selling protein biopharmaceuticals globally in 2014 (Table 2), six are antibodies or antibody-derived proteins (Humira, Remicade, Rituxan, Enbrel, Avastin, Herceptin; http:// qz.com/349929/best-selling-drugs-in-the-world/).

Formerly, biopharmaceuticals were recombinant versions of natural proteins, with the same amino acid

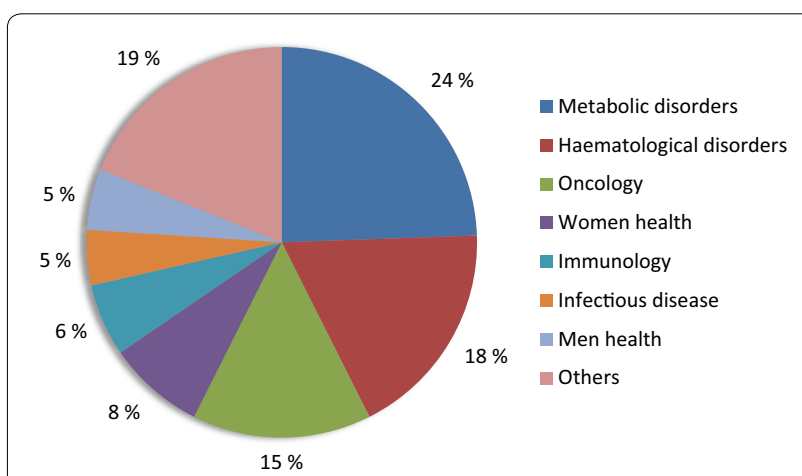

Fig. 3 Amount of marketed recombinant proteins (expressed in percentages) applied to each therapeutic area. Coloured in pink, other therapeutic areas ( $<5 \%$ each) include diseases related to cardiology, central nervous system, ophthalmology and dermatology among others

sequence as the respective native versions (with only minor modifications, often resulting from the cloning strategy). Since 1990s, a meaningful proportion of the approvals are based on highly modified forms of recombinant proteins. This novel alternative, based on protein or domain fusion and on truncated versions, offers a wide spectrum of possible combinations to obtain novel biopharmaceuticals with different joined activities that are not found together in nature.

\section{Protein drugs for cancer treatment}

Oncology is one of the therapeutic indications that dominate the biopharmaceutical market, as cancer is a major cause of morbidity and mortality worldwide. Surgery and radiotherapy are effective in curing cancer at early disease stages; however, they cannot eradicate metastatic disease. The presence of micrometastases or clinically evident metastases at diagnosis requires their use in combination with genotoxic chemotherapy to increase cure rates [38]. Nevertheless, the success of chemotherapy has been hampered because of its lack of selectivity and

Table 1 Recombinant biopharmaceuticals approved in the $1980 \mathrm{~s}$

\begin{tabular}{lll}
\hline Product & Cell factory & Therapeutic indication \\
\hline Humulin & E. coli & Diabetes \\
Protropin & E. coli & hGH deficiency \\
Roferon A & E. coli & Hairy cell leukaemia \\
IntronA & E.coli & Cancer, genital warts and hepatitis \\
Recombivax & S. cerevisiae & Hepatitis B \\
Orthoclone OKT3 & Hybridoma cell line & Reversal of acute kidney and transplant rejection \\
Humatrope & E. coli & hGH deficiency \\
Activase & CHO & Acute myocardial infarction \\
Epogen & CHO & Anaemia
\end{tabular}


Table 2 Top ten selling protein biopharmaceuticals in 2014

\begin{tabular}{|c|c|c|c|c|}
\hline Drug $^{a}$ & Active ingredient & Molecule & $\begin{array}{l}\text { Sales in } \\
\text { billions }\end{array}$ & Origin \\
\hline Humira & Adalimumab & Recombinant human monoclonal antibody & 12.54 & $\mathrm{CHO}$ \\
\hline Sovaldi & Sofosbuvir & Nucleotide analogue polymerase (NS5B) inhibitor & 10.28 & Chemical \\
\hline Remicade & Infliximab & $\begin{array}{l}\text { Recombinant chimeric, humanized tumor necrosis } \\
\text { factor alpha (TNF) monoclonal antibody }\end{array}$ & 9.24 & Hybridoma cell line \\
\hline Rituxan & Rituximab & Recombinant humanized monoclonal antibody & 8.68 & $\mathrm{CHO}$ \\
\hline Enbrel & Etanercept & Recombinant soluble dimeric fusion protein & 8.54 & $\mathrm{CHO}$ \\
\hline Lantus & Insulin glargine & Insulin receptor agonist & 7.28 & E. coli \\
\hline Avastin & Bevacizumab & Recombinant humanized antibody & 6.96 & $\mathrm{CHO}$ \\
\hline Herceptin & Trastuzumab & Recombinant humanized monoclonal antibody & 6.79 & $\mathrm{CHO}$ \\
\hline Advair & Fluticasone propionate and salmeterol xinafoate & $\begin{array}{l}\text { Glucocorticoid receptor agonist and } \beta-2 \text { adrenergic } \\
\text { receptor agonist }\end{array}$ & 6.43 & Chemical \\
\hline Crestor & Rosuvastatin calcium & Antihyperlipedemic agent & 5.87 & Synthetic \\
\hline
\end{tabular}

a Data according to www.medtrack.com, November 2015

Table 3 Representative examples of supportive protein drugs in cancer

\begin{tabular}{|c|c|c|c|c|}
\hline Drug name & Cell factory & $\begin{array}{l}\text { Biological } \\
\text { role }\end{array}$ & Mechanism of action & Indications \\
\hline Filgrastim (Scimax) & E. coli & Cytokine & Stimulates hematopoiesis & $\begin{array}{l}\text { Bone marrow transplantation and cancer } \\
\text { chemotherapy induced neutropenia }\end{array}$ \\
\hline Pegfilgrastim (Neupeg) & E. coli & Cytokine & $\begin{array}{l}\text { Stimulates differentiation, proliferation and } \\
\text { activation of the neutrophilic granulocytes }\end{array}$ & Cancer chemotherapy induced neutropenia \\
\hline Darbepoetin alfa (Aranesp) & $\mathrm{CHO}$ cells & Hormone & $\begin{array}{l}\text { Stimulates processes of erythropoiesis or red } \\
\text { blood cell production }\end{array}$ & $\begin{array}{l}\text { Anemia associated with chronic renal failure, } \\
\text { cancer chemotherapy or heart failure. } \\
\text { Myelodysplastic syndrome }\end{array}$ \\
\hline Lenograstim (CERBIOS) & $\mathrm{CHO}$ cells & Cytokine & $\begin{array}{l}\text { Stimulates differentiation, proliferation and } \\
\text { activation of neutrophilic granulocytes }\end{array}$ & $\begin{array}{l}\text { Neutropenia associated with cytotoxic } \\
\text { therapy or bone marrow transplantation }\end{array}$ \\
\hline Epoetin alfa (Binocrit) & $\mathrm{CHO}$ cells & Hormone & $\begin{array}{l}\text { Stimulates production of oxygen carrying } \\
\text { red blood cells from the bone marrow }\end{array}$ & $\begin{array}{l}\text { Anemia associated with chronic renal } \\
\text { failure and cancer chemotherapy induced } \\
\text { anemia }\end{array}$ \\
\hline
\end{tabular}

specificity, so that the toxicity to normal tissues limits the dose that could be administered to patients. The development of biopharmaceuticals capable of inhibiting specific molecular targets driving cancer (for instance, monoclonal antibodies anti-Her2-Trastuzumab- or anti-VEGFBevacizumab-) goes in this direction [39].

Among marketed protein biopharmaceuticals, almost $24 \%$ (94 products) are used in antitumoral therapies. Most of these products are used for supportive purposes intended to minimize the side effects of chemotherapy, usually neutropenia or anaemia (some representative examples are shown in Table 3). Nineteen out of those 94 products are true antitumoral drugs, $69 \%$ of which are produced in E. coli (Fig. 4) and are based on engineered amino acidic sequences, protein fusions and single protein domains (Table 4).

Clearly, modified protein versions are the most abundant in cancer therapies over natural polypeptides. As relevant examples, Ziv aflibercept is a recombinant fusion

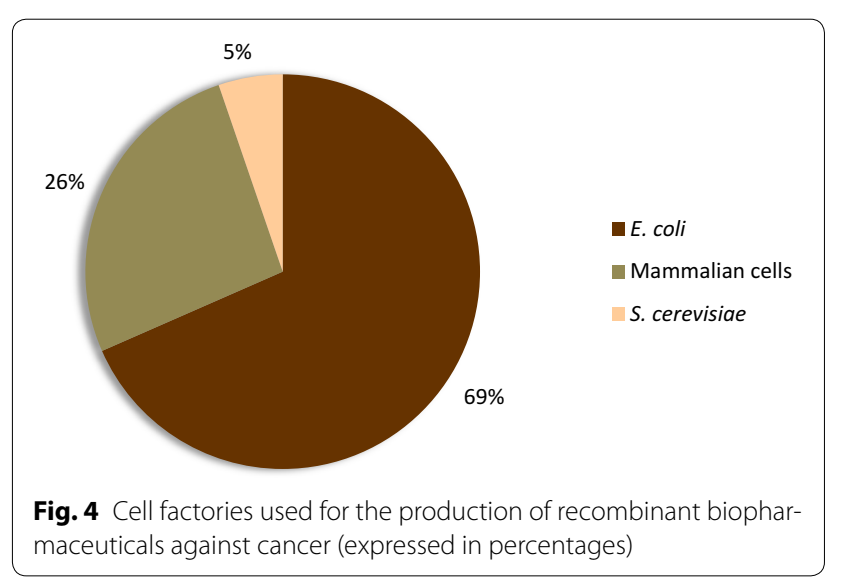

protein produced in $\mathrm{CHO}$ cells used against colorectal cancer. It consists of portions of each Vascular Endothelial Growth Factor Receptors (VEGFR1 and VEGFR2) fused 
Table 4 Anticancer recombinant biopharmaceuticals approved until March 2015

\begin{tabular}{|c|c|c|c|c|}
\hline Drug name & Cell factory & Source & Biological role & Indications \\
\hline Denileukin diftitox & E. coli & Fusion protein & $\begin{array}{l}\text { Diphtheria toxin fused } \\
\text { to cytokine }\end{array}$ & Cutaneous T-cell lymphoma \\
\hline Endostatin & E. coli & Modified & Collagen derivative & $\begin{array}{l}\text { Non-small cell lung cancer, metastatic } \\
\text { colorectal cancer }\end{array}$ \\
\hline Aldesleukin & E. coli & Modified & Cytokine & $\begin{array}{l}\text { Metastatic renal cell carcinoma, } \\
\text { metastatic melanoma, kidney cancer, } \\
\text { angiosarcoma }\end{array}$ \\
\hline Interleukin-2 & E. coli & Modified & Cytokine & $\begin{array}{l}\text { Metastatic melanoma, metastatic renal } \\
\text { cell carcinoma }\end{array}$ \\
\hline Filgrastim & E. coli & Modified & Cytokine & $\begin{array}{l}\text { Acute lymphocytic leukaemia, solid } \\
\text { tumour }\end{array}$ \\
\hline Interferon alpha-2a & E. coli & Modified & Cytokine & $\begin{array}{l}\text { AIDS-related Kaposi's sarcoma, follicular } \\
\text { lymphoma, cutaneous T-cell lym- } \\
\text { phoma, melanoma, chronic myelo- } \\
\text { cytic leukaemia, hairy cell leukaemia, } \\
\text { renal cell carcinoma, kidney cancer }\end{array}$ \\
\hline Interferon alpha-2b & E. coli & Modified & Cytokine & $\begin{array}{l}\text { AIDS-related Kaposi's sarcoma, pancre- } \\
\text { atic endocrine tumour, melanoma, } \\
\text { non-Hodgkin lymphoma, leukae- } \\
\text { mia, hairy cell leukaemia, renal cell } \\
\text { carcinoma, multiple myeloma, CML, } \\
\text { follicular lymphoma, melanoma }\end{array}$ \\
\hline Interferon alpha-1b & E. coli & Modified & Cytokine & $\begin{array}{l}\text { Renal cell carcinoma, hairy cell leukae- } \\
\text { mia }\end{array}$ \\
\hline Interferon gamma-1a & E. coli & Modified & Cytokine & $\begin{array}{l}\text { Kidney cancer, sezary syndrome, myco- } \\
\text { sis fungoides }\end{array}$ \\
\hline Tasonermin & E. coli & Natural & Cytokine & Soft tissue sarcoma \\
\hline Molgramostim & E. coli & Modified & Growth factor & Myelodysplastic syndrome \\
\hline Nartograstim & E. coli & Modified & Growth factor & Solid tumour \\
\hline Palifermin & E. coli & Fraction & Growth factor & $\begin{array}{l}\text { Metastatic renal cell carcinoma, meta- } \\
\text { static melanoma }\end{array}$ \\
\hline Sargramostim & S. cerevisiae & Modified & Growth factor & Acute myelocytic leukaemia \\
\hline Ziv-aflibercept & CHO cells & Fusion protein & $\begin{array}{l}\text { Growth factor receptor } \\
\text { fused to lgG1 }\end{array}$ & Metastatic colorectal cancer \\
\hline Thyrotropin alpha & $\mathrm{CHO}$ cells & Modified & Hormone & Thyroid cancer \\
\hline Trastuzumab biosimilar & $\mathrm{CHO}$ cells & Modified & Monoclonal antibody & $\begin{array}{l}\text { Breast cancer, gastric cancer, metastatic } \\
\text { breast cancer }\end{array}$ \\
\hline Rituximab biosimilar & $\mathrm{CHO}$ cells & Modified & Monoclonal antibody & $\begin{array}{l}\text { Non-Hodgkin lymphoma, chronic } \\
\text { lymphocytic leukaemia }\end{array}$ \\
\hline Interferon alpha & $\begin{array}{l}\text { Human lymphoblastoid } \\
\text { cells }\end{array}$ & Modified & Cytokine & $\begin{array}{l}\text { AIDS-related Kaposi's sarcoma, multiple } \\
\text { myeloma, non-Hodgkin lymphoma, } \\
\text { CML, hairy cell leukaemia, renal cell } \\
\text { carcinoma }\end{array}$ \\
\hline
\end{tabular}

to the constant fraction $(\mathrm{Fc})$ of a human IgG1 immunoglobulin (Fig. 5). This construct acts as a decoy by binding to VEGF-A, VEGF-B and placental growth factor (PlGF), which activate VEGFR. This trap hinders the interaction between the growth factors and the receptors, inhibiting the VEGF pathway which is involved in the angiogenic process [40]. Denileukin diftitox is a recombinant protein composed of two diphtheria toxin fragments (A and B) and a human interleukin-2 (Fig. 5). Diphteria toxin is a potent exotoxin secreted by Corynebacterium diphteriae.
Due to its peculiar structure, the whole complex, produced in $E$. coli, is capable of delivering a cytotoxic agent directly to a specific target. There are two main active blocks whose function is firstly to selectively deliver the biopharmaceutical (IL-2) and secondly cause cytotoxicity (toxin A and B) [41]. The fusion protein binds to the IL-2 receptor, which is expressed in cancerous cells (cutaneous $\mathrm{T}$ cell lymphoma). Once the toxin moiety is internalized, the catalytic domain promotes cell death through protein synthesis inhibition [42]. 


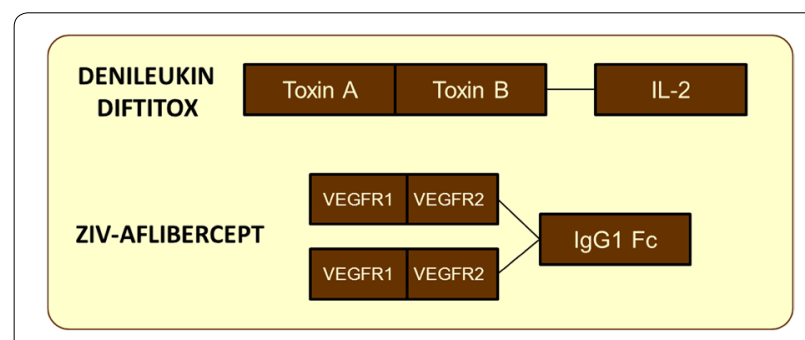

Fig. 5 Schematic molecular structure of two marketed recombinant biopharmaceuticals

As targeted drug delivery for cancer is a most recent and expanding area of research, other non-recombinant, protein-based biopharmaceuticals are also heavily represented. Those mainly include antibody-drug conjugates (ADCs) such as Brentuximab vedotin, Trastuzumab emtansine, or nanoparticle-drug conjugates such as nab-paclitaxel [39, 43]. In these cases, the protein counterpart acts as a targeted vehicle for conventional chemical drugs. Again, this approach pursues the selective drug delivery to specific target cells, aimed to increase antitumoral activity while reducing toxicity on normal cells and the associated side effects.

Products against cancer that provided the highest revenues in 2013 are represented in Fig. 6. Sixty
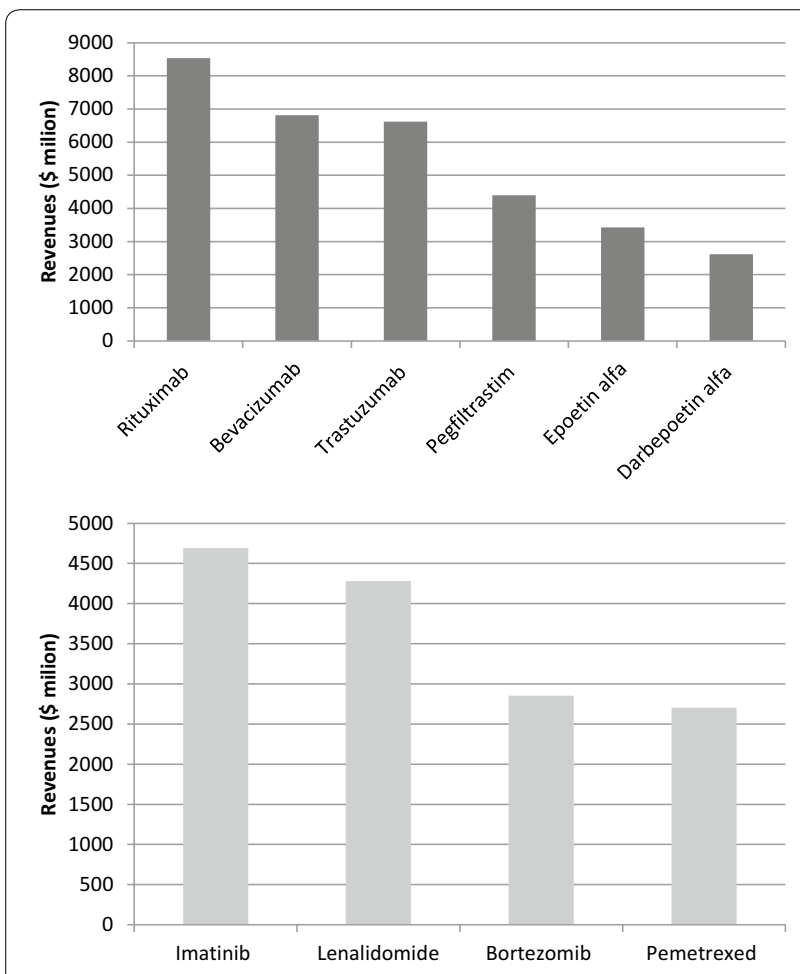

Fig. 6 Income provided by recombinant (top) and chemical drugs (bottom) against cancer in 2013. Figures according to Global Data [9] percent of those products are recombinant proteins, supporting the idea that recombinant protein production is still a rising and promising platform, offering room for important advances in the biopharmaceutical sector.

\section{Conclusions}

In summary, the market and potential for recombinant drugs is expanding by taking advantage of a steady growing spectrum of protein production platforms. Despite the strength of mammalian cell lines as factories, microbial cells and specially $E$. coli are still potent protein factories essentially supported by their versatility and cost-effective cultivation. Recombinant drugs are moving from plain recombinant versions of natural products to more sophisticated protein constructs resulting from a rational design process. Combining protein domains to gain new functionalities is being exploited in drug discovery by exploiting the structural and functional versatility that merge in proteins as extremely versatile macromolecules.

\section{Abbreviations}

AIDS: acquired immune deficiency syndrome; ADCs: antibody-drug conjugates; CHO: chinese hamster ovary; CML: chronic myelogenous leukemia; Fc: constant fraction; FDA: food and drug administration; hGH: human growth hormone; IL: interleukin; PIGF: placental growth factor; VEGF: vascular endothelial growth factor; VEGFR: vascular endothelial growth factor receptor.

\section{Authors' contributions}

LSG performed most of the bibliographic search and prepared part of the text, tables and figures, under the supervision of NFM and EV. LM and RM contributed with additional information and revised the manuscript. AV coordinated the whole revision, prepared part of the text and figures and the final manuscript version. All authors read and approved the final manuscript.

\section{Author details}

1 Institut de Biotecnologia i de Biomedicina, Universitat Autònoma de BarceIona, 08193 Bellaterra, Cerdanyola del Vallès, Spain. ${ }^{2}$ Departament de Genètica i de Microbiologia, Universitat Autònoma de Barcelona, 08193 Bellaterra, Cerdanyola del Vallès, Spain. ${ }^{3}$ CIBER de Bioingeniería, Biomateriales y Nanomedicina (CIBER-BBN), 08193 Bellaterra, Cerdanyola del Vallès, Spain. ${ }^{4}$ Technology Transfer Office, Edifici Eureka, Universitat Autònoma de Barcelona, 08193 Bellaterra, Cerdanyola del Vallès, Spain. ${ }^{5}$ Institut d'Investigacions Biomèdiques Sant Pau, Josep Carreras Research Institute and CIBER-BBN, Hospital de la Santa Creu i Sant Pau, Barcelona, Spain.

\section{Acknowledgements}

The authors appreciate the funding for protein drug development received from MINECO (BIO2013-41019-P), AGAUR (2014SGR-132, 2014PROD-00055) CIBER de Bioingeniería, Biomateriales y Nanomedicina (NANOPROTHER), Marató de TV3 foundation (TV32013-132031, TV32013-3930) and ISCIII FIS (PI12/00327, PI15/00272, PI15/00378). LSG received a Lanzadera fellowship from CIBER-BBN, and AV received an ICREA ACADEMIA award.

\section{Competing interests}

The authors declare that they have no competing interests.

Received: 3 December 2015 Accepted: 1 February 2016

Published online: 09 February 2016 


\section{References}

1. Vajo Z, Fawcett J, Duckworth WC. Recombinant DNA technology in the treatment of diabetes: insulin analogs. Endocr Rev. 2001;22:706-17.

2. Takeda A, Cooper K, Bird A, Baxter L, Frampton GK, Gospodarevskaya E, et al. Recombinant human growth hormone for the treatment of growth disorders in children: a systematic review and economic evaluation. Health Technol Assess. 2010;14:1-4.

3. Cutting GR. Modifier genetics: cystic fibrosis. Annu Rev Genomics Hum Genet. 2005;6:237-60.

4. Weatherall DJ. Phenotype-genotype relationships in monogenic disease: lessons from the thalassaemias. Nat Rev Genet. 2001:2:245-55.

5. Powell JS. Lasting power of new clotting proteins. Hematology Am Soc Hematol Educ Program. 2014;2014:355-63.

6. Hirschhorn JN, Lohmueller K, Byrne E, Hirschhorn K. A comprehensive review of genetic association studies. Genet Med. 2002:4:45-61.

7. Savic S, McDermott MF. Clinical genetics in 2014: new monogenic diseases span the immunological disease continuum. Nat Rev Rheumatol. 2015;11:67-8

8. Assenberg R, Wan PT, Geisse S, Mayr LM. Advances in recombinant protein expression for use in pharmaceutical research. Curr Opin Struct Biol. 2013;23:393-402.

9. Global Data 2015. http://www.globaldata com. 2015

10. Lammers T, Aime S, Hennink WE, Storm G, Kiessling F. Theranostic nanomedicine. Acc Chem Res. 2011:44:1029-38.

11. Pene F, Courtine E, Cariou A, Mira JP. Toward theragnostics. Crit Care Med. 2009;37:S50-8.

12. Demain AL, Vaishnav P. Production of recombinant proteins by microbes and higher organisms. Biotechnol Adv. 2009;27:297-306.

13. Adrio JL, Demain AL. Recombinant organisms for production of industrial products. Bioeng Bugs. 2010;1:116-31.

14. Walsh G. Biopharmaceutical benchmarks 2014. Nat Biotechnol. 2014;32:992-1000.

15. Ferrer-Miralles N, Villaverde A. Bacterial cell factories for recombinant protein production; expanding the catalogue. Microb Cell Fact. 2013;12:113.

16. Corchero JL, Gasser B, Resina D, Smith W, Parrilli E, Vazquez F, et al. Unconventional microbial systems for the cost-efficient production of high-quality protein therapeutics. Biotechnol Adv. 2013;31:140-53.

17. Ferrer-Miralles N, Domingo-Espin J, Corchero JL, Vazquez E, Villaverde A. Microbial factories for recombinant pharmaceuticals. Microb Cell Fact. 2009:8:17.

18. Zhu J. Mammalian cell protein expression for biopharmaceutical production. Biotechnol Adv. 2012;30:1158-70.

19. Baeshen NA, Baeshen MN, Sheikh A, Bora RS, Ahmed M, Ramadan HI, et al. Cell factories for insulin production. Microb Cell Fact. 2014;13:141.

20. Overton TW. Recombinant protein production in bacterial hosts. Drug Discov Today. 2014;19:590-601.

21. Chen R. Bacterial expression systems for recombinant protein production: E. coli and beyond. Biotechnol Adv. 2012;30:1102-7.

22. van Dijl JM, Hecker M. Bacillus subtilis: from soil bacterium to super-secreting cell factory. Microb Cell Fact. 2013;12:3.

23. Cano-Garrido O, Rueda FL, Sanchez-Garcia L, Ruiz-Avila L, Bosser R, Villaverde $A$, et al. Expanding the recombinant protein quality in Lactococcus lactis. Microb Cell Fact. 2014:13:167.
24. Su X, Schmitz G, Zhang M, Mackie RI, Cann IK. Heterologous gene expression in filamentous fungi. Adv Appl Microbiol. 2012;81:1-61.

25. Decker EL, Reski R. Current achievements in the production of complex biopharmaceuticals with moss bioreactors. Bioprocess Biosyst Eng. 2008;31:3-9.

26. Decker EL, Reski R. Moss bioreactors producing improved biopharmaceuticals. Curr Opin Biotechnol. 2007;18:393-8.

27. Basile G, Peticca M. Recombinant protein expression in Leishmania tarentolae. Mol Biotechnol. 2009:43:273-8.

28. Kushnir S, Gase K, Breitling R, Alexandrov K. Development of an inducible protein expression system based on the protozoan host Leishmania tarentolae. Protein Expr Purif. 2005;42:37-46.

29. Breitling R, Klingner S, Callewaert N, Pietrucha R, Geyer A, Ehrlich G, et al. Non-pathogenic trypanosomatid protozoa as a platform for protein research and production. Protein Expr Purif. 2002;25:209-18.

30. Mamat U, Wilke K, Bramhill D, Schromm AB, Lindner B, Kohl TA, et al. Detoxifying Escherichia coli for endotoxin-free production of recombinant proteins. Microb Cell Fact. 2015;14:57.

31. Ueda T, Akuta T, Kikuchi-Ueda T, Imaizumi K, Ono Y. Improving the soluble expression and purification of recombinant human stem cell factor (SCF) in endotoxin-free Escherichia coli by disulfide shuffling with persulfide. Protein Expr Purif. 2016;120:99-105.

32. Rueda F, Cano-Garrido O, Mamat U, Wilke K, Seras-Franzoso J, Garcia-Fruitos $\mathrm{E}$, et al. Production of functional inclusion bodies in endotoxin-free Escherichia coli. Appl Microbiol Biotechnol. 2014;98:9229-38.

33. Taguchi S, Ooi T, Mizuno K, Matsusaki H. Advances and needs for endotoxin-free production strains. Appl Microbiol Biotechnol. 2015;99:9349-60.

34. Rader RA. (Re)defining biopharmaceutical. Nat Biotechnol. 2008;26:743-51

35. Walsh G. New biopharmaceuticals. Biopharm Int. 2012;25:34-8.

36. Anonymous. Human insulin receives FDA approval. FDA Drug Bull. 1982;12:18-9.

37. Johnson IS. Human insulin from recombinant DNA technology. Science. 1983:219:632-7.

38. Chabner BA, Roberts TG Jr. Timeline: chemotherapy and the war on cancer. Nat Rev Cancer. 2005;5:65-72.

39. Scott AM, Wolchok JD, Old LJ. Antibody therapy of cancer. Nat Rev Cancer. 2012;12:278-87.

40. Patel A, Sun W. Ziv-aflibercept in metastatic colorectal cancer. Biologics. 2014;8:13-25

41. Manoukian G, Hagemeister F. Denileukin diftitox: a novel immunotoxin. Expert Opin Biol Ther. 2009;9:1445-51.

42. Ho VT, Zahrieh D, Hochberg E, Micale E, Levin J, Reynolds C, et al. Safety and efficacy of denileukin diftitox in patients with steroid-refractory acute graft-versus-host disease after allogeneic hematopoietic stem cell transplantation. Blood. 2004;104:1224-6.

43. Lohcharoenkal W, Wang L, Chen YC, Rojanasakul Y. Protein nanoparticles as drug delivery carriers for cancer therapy. Biomed Res Int. 2014;2014:180549

\section{Submit your next manuscript to BioMed Central and we will help you at every step:}

- We accept pre-submission inquiries

- Our selector tool helps you to find the most relevant journal.

- We provide round the clock customer support

- Convenient online submission

- Thorough peer review

- Inclusion in PubMed and all major indexing services

- Maximum visibility for your research

Submit your manuscript at www.biomedcentral.com/submit
C Biomed Central 